\title{
Cymbeline: Arithmetic, Double-Entry Bookkeeping, Counts, and Accounts
}

\author{
Patricia Parker \\ Stanford University
}

\begin{abstract}
The importance of commercial arithmetic and double-entry bookkeeping (or "debitor and creditor" accounting) has been traced in The Merchant of Venice, Othello, the Sonnets, and other works of Shakespeare and his contemporaries. But even though both are explicitly cited in Cymbeline (the only Shakespeare play other than Othello to invoke double-entry by its contemporary English name), their importance for this late Shakespearean tragicomic romance has yet to be explored. This article traces multiple ways in which Cymbeline is impacted by arithmetic and the arts of calculation, risk-taking, surveying, and measuring; its pervasive language of credit, usury, gambling, and debt, as well as slander infidelity and accounting counterfeiting; the contemporary conflation of the female " $\mathrm{O}$ " with arithmetic's zero or "cipher" in relation to alleged infidelity; and the larger problem of trust (from credere and credo) that is crucial to this play as well as to early modern England's culture of credit.

KEYWORDS: Cymbeline, Shakespeare, double-entry bookkeeping, Hindu-Arabic numbers, arithmetic, military science, feminist criticism, gender, transvestite theatre, knowledge production, rhetoric, mathematics, history of accounting, economic criticsm.
\end{abstract}

The importance of arithmetic and double-entry bookkeeping for Shakespeare has been traced in The Merchant of Venice, the Sonnets, and other works. ${ }^{1}$ But though Cymbeline explicitly cites both, their

1 See inter alia Parker (1987:132-140; 2004:25-49; 2009:223-241); Bady (1985:10-30); Woodbridge (2003:1-18; 2010:328-329); Glimp and Warren (2004); Blank (2006:118152); Korda (2009:129-153); Raman (2008:158-80; 2010:212-231).

(9) ederi 23 (2013: 95-119)

https:// doi.org/10.34136/sederi.2013.5 
importance for this late play has still to be explored. This article will argue that the new "arithmetic" and "debitor and creditor" or double-entry accounting are crucial for Cymbeline, the only play in the canon other than Othello $(1.1 .19,31)$ to invoke both "arithmetic" (2.4.142) and "debitor and creditor" accounting by its contemporary name (5.3.228-229). ${ }^{2}$ It will also foreground preoccupations that bring this tragicomic romance closer to other Shakespeare plays that have been the focus of commercial and economic criticism.

As the form of counting (arithmos) "used by merchants or bankers when buying or selling in the marketplace" (Jaffe 1999:29), arithmetic was identified with mercantile calculations and the Hindu-Arabic numerals, including the sifr, cipher, or zero. Robert Recorde (1543:6) noted that some call it "Awgrym for Algorisme (as Arabyans founde it)." Despite its advantages over tally-sticks, counters, and Roman numerals, there was "bitter resistance" to this so-called "infidel" system (Bernstein 1996:35). In England, this "new arithmetic of the pen," with its "strange and unfamiliar" numerals, was resisted well into the seventeenth century (Thomas 1987:120121). Arithmetic and double-entry treatises continued to include "counters" for "such as lacke the knowledge of Arithmetike by the Penne" (Mellis 1588: A7v), a combination reflected in the "counters" and "pen" reckoning of Cymbeline (5.3.228-230), as well as in Florentine Cassio as both "counter-caster" and "arithmetician" in Othello (1.1.31).

Central to this resistance was the "infidel symbol" zero (Rotman 1987:8), "sign for what was not" (Crosby 1997:113), identified through "cipher" with enigmatic signs or writing to be "deciphered" (Jaffe 1999:87) in ways suggestive for Cymbeline's enigmas and decipherings. Written like the letter " $\mathrm{O}$ " (Menninger 1969:412), it was associated with the female sexual " $\mathrm{O}$ " or "count" and feared infidelity of this hidden "nothing" or "country matters" (Hamlet 3.2.116). The "cipher" of this new place-based arithmetic is able to "Attest in little place a million" in Henry $V$, where actors on the Globe's "wooden O" become "ciphers" to a "great accompt" (Prologue 15-17) and "le count" of Katherine's female body joins the

\footnotetext{
${ }^{2}$ Evans (1997) is cited for Shakespeare plays other than Cymbeline (cited from Butler 2005). Butler retains Folios' Iachimo; but changes Imogen to Innogen (suggesting "innocence"), wife of Leonato in Much Ado About Nothing, and familiar from Cymbeline's sources and Simon Forman's 1611 account.
} 
inventory of Henry's hoped-for possessions (3.4.51-59) (Parker [1987:138]; Turner [2006:10]; Parker [2009:232, 236-237]). Othello fears that Desdemona has "the act of shame|A thousand times committed" (5.2.212). In The Winter's Tale, the "cipher" able to "multiply" one into "many thousands more" figures not only a "debt" but the "rich place" of Hermione's pregnant body (1.2.6-8; Parker 2004:39); and the feared infidelity of this " $\mathrm{O}$ " spirals into Leontes' jealous "nothings" (1.2.284-296). In Cymbeline, when Posthumus concludes that Innogen has turned "whore," his "Spare your arithmetic, never count the turns. |Once, and a million!" (2.4.142143) echoes the sexual "turns" of Othello (4.1.252) and the female "count" of Henry $V$.

Suggestively for Cymbeline's preoccupation with sexual, epistemological, and cognitive knowing, "vulgar Arithmeticke" brought the unknown "thing" to light; and this $\cos a$ or "thing" was linked to uncovering a female res or thing (Bady 1985:11; Parker 2009:228). Iachimo's account of Innogen's "chamber" (2.4.81) convinces Posthumus he has had carnal "knowledge" of her (2.4.51). "Arithmetic" was identified with sexual "commerce" as well as what Measure for Measure called "the two usuries" (3.2.5), sexual and monetary (Hawkes 2010:164-165). "Turnbull Street whores" were described as practicing "arithmetic"; the "Arithmaticke" of a "Bawd" included carnal as well as commercial "Divisions \& Multiplications" (Williams 1994:2.863-864). The association of arithmetic with usury of both kinds is reflected not only in Othello (2.1.130), but in Cymbeline as well, a play whose pervasive language of debts includes "the city's usuries" (3.3.45) but also the sexual debt de mariage that Posthumus fears has been paid to another. ${ }^{3}$

Famously anachronistic, Cymbeline combines ancient Britain and Augustus Caesar's Rome with a "bourgeois" wager plot from Florentine Boccaccio's Decameron and the anonymous Frederyke of

\footnotetext{
3 On marital sexual "debt," "interest," and usury, see Fischer (1985:51) ("cancel"); Korda (2009:151-152). On Cymbeline's language of debt and commerce, see Spurgeon (1935:296-300); Parker (1987:132-137); Siemon (1994:294-309); Stanivukovic (1998:229243); Wayne (2002:288-315); Ryner (2008:77-94); Gillen (2011:1-38). Its "bonds" include marital bonds, what is owed by daughter to father ("duty [...] unpaid," 3.5.48), servants to masters (5.1.7), obligatio, religio, and other ties that bind (e.g. 3.7.15). "His steel was in debt, it went o'th'backside the town" (1.2.8) connects bodily backside to backstreets where debtors evade creditors.
} 
Jennen or Genoa. ${ }^{4}$ The name choice "Europhile" (4.2.233) is joined by the Europeans of the wager scene, which includes "a Dutchman," " $a$ Spaniard" (1.4.0 SD), a "Frenchman," Posthumus the "Briton," and the "Italian" gentlemen Philario and Iachimo, later identified as "Siena's brother" (4.2.340). Siena, like Florence, Venice, and Genoa, had a long history of the rise of merchants and merchant-bankers to the status of aristocrats and "gentles," as well as connections to the commercial "arithmetic" and "debitor and creditor" accounting that Cymbeline invokes.

The association of "arithmetic" with merchants and trades rather than "gentles" (Woodbridge 2003:3; Blank 2006:124) is part of the double perspective in Cymbeline on Cloten's arithmetical deficiencies, which suggest his class disdain for "numbers" while ridiculing his ineptitude at calculation, in contrast to his mother the Queen who is always "coining plots" (2.1.53) and the calculating Iachimo identified with early modern Italy. Not just merchants, however, but even aristocrats and "gentles" were increasingly part of England's "culture of credit" (Muldrew 1998), which included not only commercial arithmetic but also wager-laying, including betting on horses, cards, dice, and dueling (all alluded to in Cymbeline). ${ }^{5}$ Cloten, Posthumus, and Iachimo engage in gambling with differing degrees of skill; the war against Rome is improbably won against high odds; and the play's wager, risk-taking, revenge, slander, and other plots repeatedly invoke not only "arithmetical" reckonings, credits, debts, and accounts both financial and narrative, but also military risk-taking, the "hazard" $(1.4 .76 ; 4.4 .6)$ Guiderius complains he and his brother have been kept from, before their crucial role in defeating the invading Romans.

The new arithmetic-where value depended on place because its "figures" acquired a different value depending on their placement was identified with "place" more generally in contemporary writing,

\footnotetext{
4 See Wayne (2008:163-187) on these and other wager stories; Parker (1989:189-104); Parolin (2002:188-215).

${ }^{5}$ Although her more detailed play analyses do not include Cymbeline, Woodbridge (2010:61-126) on arithmetic, double-entry, gambling, "bonds," debts, and revenge as "pay-back" provides suggestive contexts for it. Bernstein (1996:39-56) traces gambling risk calculation and probability theory from Pacioli (1494) to Italian arithmetician/ gambler Girolamo Cardano (on whom see also Bady [1985:12]; Woodbridge [2003:8] on his 1552 visit to England).
} 
including hierarchical or social place and upward or downward mobility (Parker 2009:226), major preoccupations in Cymbeline. At the same time, it was bound up with other developments that required calculating and measurement, in ways Cymbeline reflects, including visual perspectives, land surveying, military science, and "debitor and creditor" accounting. This play's intersections of "place" and "perspective" are underscored in Wales, where Belarius's "it is place which lessens and sets off" (3.3.13) combines hierarchical "place" with the eye's viewing or vantage point. "Debitor and creditor" bookkeeping is invoked here, from Belarius's perspective, in his rejection of "the city's usuries" (3.3.45) and debts "uncrossed" in a double-entry ledger "book" (3.3.26); but the reverse perspective of Guiderius sees their rural "cell of ignorance" as a "prison for a debtor that not dares | To stride a limit" (34-35).

Visual perspectives are repeatedly evoked in Cymbeline, not only in the different ways characters look (both objectively and subjectively), but also in act 5 , where "debitor and creditor" accounting is invoked in relation to what is "true" (5.3.228). Posthumus forgives Innogen for "wrying but a little" (5.1.5) after he is convinced by the "bloody cloth" (5.1.1) that she has been murdered as he ordered. But "wrying" as a term subtly recalls Richard II, on the importance of looking at "perspectives" themselves "awry," since they show "nothing but confusion" when "rightly gazed upon" (2.2.18-20). And Innogen has never actually been "awry," crooked or obliquely turned, in the sense of sexual infidelity Posthumus's "wrying" continues to assume.

Cymbeline's evocation of land surveying combines perspective with arithmetical calculation. It repeatedly recalls moments in Virgil's Aeneid when tracts of land (or time) are surveyed from a superior vantage point, a central scopic image of Roman imperium. Jupiter's overarching perspective on the plot of Aeneas's trials is recalled in the descent of "Jupiter" in Cymbeline 5.3 (Parker 1989:194).

\footnotetext{
6 Turner (2006:166-169) on the verbal creation of visual perspective in King Lear is suggestive for Cymbeline as well. See also Cymbeline's references to "mapped" (4.1.2); counting or numbering (1.6.37), including military "numbers" (3.7.15; 4.2.342); "quantity" and "weight" (e.g. 4.2.17); and measuring (1.1.27; 1.2.16; 2.4.113; 3.6.62).

7 Leon Battista Alberti, designer of spaces, secret ciphers, and visual perspectives, lived late in life with Pacioli, whose Summa (1494) included arithmetic and doubleentry (Poovey 1998:37).
} 
But Cymbeline combines such "Roman" moments with reminders of contemporary "arithmetic," including calculation of the distance to Milford Haven (3.2.50-74), which, from the higher elevation of a "mountain-top," seems much closer (3.6.4-6). Such moments of "perspective" in Cymbeline are related to assessing "prospects" in multiple senses - surveying a prospect of land or calculating a distance, but also calculating future prospects, including profit or vantage, as Iachimo calculates his prospects before laying his bet in the wager plot.

The new arts of calculation included the plotting of battle formations and surveying of "plots" or plats that connected the theater of war to theater itself (Turner 2006:43-81). Cymbeline combines Roman military terms with anachronistic references to "knights o'th'battle" (5.4.20; Edelman 2000:188, 195-196, 411) and the new military arithmetic that used the "infidel symbols" identified with commerce. "Hazard" (4.4.46), for military risk, recalls the description in English military treatises of Julius Caesar's famous dice throw (Alea iacta, "the die is cast"), used by "Spaniards in the Low Countries" (Edelman 2000:168); but also Shakespeare's Richard III ("I have set my life upon a cast|And I will stand the hazard of the die," 5.4.9-10), a gamble lost to the future Tudor king associated with Milford Haven in Wales.

The rise of military arithmetic was spurred by the Turk, whose soldiers were "the most effective infantry force the world had seen since the days of the Roman legions" (Edelman 2000:369-372), the Ottoman successor to ancient Rome opposed to Hapsburg Charles V as "Holy Roman Emperor." Its other major impetus was military engagement in the Low Countries, where English Protestants sided with Dutch against Spanish, a war pertinent to Cymbeline because Cymbeline's concluding peace with Rome recalls James's peace with Spain. ${ }^{8}$ Though many English gentlemen resisted commercial

\footnotetext{
8 "Impious turbans" (3.3.6) in a scene recalling Augustan Rome (Parker 1989:202) would evoke Constantinople, more than once a "new Rome," and not simply preOttoman Saracens. "Dutchman" and "Spaniard" in the wager scene evoke the Low Countries as both commercial arithmetic and bookkeeping center (whose Antwerp Burse was model for Gresham's London Exchange) and battlefield on which Englishmen fought before and after Antwerp's fall in 1585. Antwerp in Brabant and the Low Countries' wars were earlier recalled in the name-choice Brabantio and echoes of $A$ Larum for London in Othello (including 2.3, where Cassio is "cashier'd").
} 
arithmetic, military strategizing required arithmetic's calculations. The Arithmeticall Militarie Treatise, Named Stratioticos (1579), by the gentlemen Leonard and Thomas Digges, appended "military examples to the usual commercial examples" (Woodbridge 2003:7). ${ }^{9}$ The 1588 Spanish Armada, recalled in Cymbeline's Roman invasion of Britain, led to a new spate of arithmetic books reflecting military and commercial needs (Woodbridge 2003:4-7). ${ }^{10}$ An expanded Stratioticos was published in 1590 by Richard Field, prolific publisher of commercial and military arithmetics (Woodbridge 2003:7), as well as Shakespeare's fellow-Stratfordian and publisher of Venus and Adonis and The Rape of Lucrece. His name is cryptically alluded to in Cymbeline as "Richard du Champ" (4.2.376).

The combination of military with commercial is foregrounded on Cymbeline's multiple fields of battle. In the wager scene, Iachimo pictures Innogen as both military ensign-bearer for Posthumus and underwriter of this "beggar's" inflated value (1.4.14-17). "Arrearages" (2.4.13) of Britain's unpaid "tribute" debt lead to Rome's invasion. Posthumus's detailed narrative account in 5.3, of the battle the audience has just seen, is a recounting of the heroism of "two striplings" and "an ancient soldier, | An honest one, I warrant" (15-19), which becomes a reckoning of numbers against the outnumbered (without mentioning he was the "fourth," 86). The bravery of "These three, | Three thousand confident, in act as many |For three performers are the file when all|The rest do nothing" (5.2.28-31) turns the losing battle other Britons are fleeing into the Romans as "ten chased by one" and Britons as "each one the slaughterman of twenty" (5.3.48-49). But when the British lord who was one of the "fliers" (5.3.2) reduces his detailed account to "A narrow lane, an old man, and two boys!" (5.3.52), Posthumus responds "Will you rhyme upon't, $\mid$ And vent it for a mock'ry? Here is one:|'Two boys, an old man twice a boy, a lane,|Preserved the Britons, was the Romans' bane" (5.3.55-58). His parody of such reductive summing up recalls both folk sayings and the cryptic riddles of commercial arithmetics, just as "vent it for a mockery"

\footnotetext{
${ }^{9}$ Stratioticos has been cited, with other such texts, in relation to Iago's contempt for the "bookish theoric" of Cassio the "arithmetician" in Othello (Edelman 2000:357).

${ }^{10} 1588$ also saw the first English translation of work on artillery by Niccolò Tartaglia (Woodbridge 2003:7), whose career included commercial arithmetic, bookkeeping, and surveying.
} 
(from vendre to sell, as well as publish) expresses contempt that the heroism that defeated the Romans against all odds could be reduced to a commercially exploitable "rhyme."

All of these instances are related to the new "arithmetic" invoked in Cymbeline, including Posthumus's narrative accounting to someone not present. What follows now turns to accounting itself, the Jailer's invocation of "debitor and creditor" bookkeeping (5.3.228-229) and its importance for this play's wager and slander plots, commercial preoccupations, and other accounts, including those provided by Iachimo, culminating in his own extended account in the Recognition Scene.

After Posthumus (longing for death) has changed from "Briton" to "Roman" to be imprisoned and executed, had his dream of his Leonati family, and been unable to decipher the text left by Jupiter, his British Jailer enters:

JAILER Come, sir, are you ready for death?

POSTHUMUS Over-roasted rather; ready long ago.

JAILER Hanging is the word, sir. If you be ready for that, you are well cooked.

PosthumUs So if I prove a good repast to the spectators, the dish pays the shot.

JAILER A heavy reckoning for you, sir. But the comfort is, you shall be called to no more payments, fear no more tavern bills, which are as often the sadness of parting as the procuring of mirth. You come in faint for want of meat, depart reeling with too much drink; sorry that you have paid too much, and sorry that you are paid too much; purse and brain both empty: the brain the heavier for being too light, the purse too light, being drawn of heaviness. Of this contradiction you shall now be quit. O the charity of a penny cord! It sums up thousands in a trice. You have no true debitor and creditor but it: of what's past, is, and to come, the discharge. Your neck, sir, is pen, book, and counters; so the acquittance follows. (5.3.214-230)

The Jailer invokes "counters" together with the "book" of "debitor and creditor" and arithmetic of the "pen," able, like the hangman's rope, to "sum up thousands in a trice," in an exchange filled with the commercial, legal, and biblical language of credit, debt, and "acquittance." Its biblical echoes include the lex talionis and 
"measure" (Matthew 7:2) that provided the title of Measure for Measure; the forgiveness of debts or trespasses; Redemption from an unpayable debt; and the final Reckoning, Last Judgment, or Audit. ${ }^{11}$ Its equivoques include "acquittance" as discharging a debt to usurious creditors and the debt/death owed to God; "reckoning" as "paying a tavern bill" and "making an atonement"; Posthumus's body as a "dish" that "pays the shot" or bill and a meal worth its price. "Sorry that you have paid too much, and sorry that you are paid too much" includes (a) "have paid" as depleted of ready cash or coins and (b) "are paid" as "paid" back (4.2.245), evocative of Cymbeline's plots of revenge as "payback."

At the same time, the Jailer's language foregrounds the sexual, bodily and monetary associated with "arithmetic" and "accounts" of "debitor and creditor." "Purse too light, being drawn of heaviness" suggests both "emptied (of the coins) that made it weighty" (Butler 2005:223); and the empty bodily "purse" of the impotent "fool" Cloten (4.2.112), who may have been played by the same actor. "Heavy" and "light" recalls the biblical burden that is paradoxically "light" but also the "light" women and heavy "purse" of sexual commerce. The repeated sound of " $\mathrm{O}$ " leading to "sums up thousands in a trice. You have no true debitor and creditor but it" evokes the female "O," sexual arithmetic's "infidel" cipher. ${ }^{12}$ But it also suggests (in "true") that if the female "count" is suspect as "untrue" (as Posthumus assumes of Innogen's "wrying"), no earthly accounting or perspective, including his, is reliably "true" either.

The combination of "debitor and creditor" with unpaid "debt" makes this British prison symbolically a debtor's prison, in ways that resonate within Cymbeline. Its pervasive references to prisons, locks, and "manacles" evoke not only usurious creditors but also debtor's prisons, including the "Counter" in Southwark exploited in bawdy contemporary wordplay on bodily "counts," "accounts," and the

\footnotetext{
${ }^{11}$ See Parker (1996:56-82; 2009:228-233) on these biblical-financial terms, including "redemption"; Matthew (18:21-35; 25:14-30: Parable of the Talents and "faithful steward"), central to debates over usury, interest or "vantage" (Hawkes 2010:83-93); Luke 6:35; Woodbridge (2010:89-93) on owing God a death, Christ's paying an unpayable debt, and "forgive us our debts" (Matthew 6:12).
}

${ }^{12}$ I agree with Nosworthy (1955:162) on not emending the first Folio "Oh" to "Of." 
"counters" used for reckoning unpaid bills. ${ }^{13}$ The Jailer's speech echoes the Henriad's tavern scenes and Falstaff's debts to the "Hostess" both financial and sexual, debts he promises to pay but continues to put off, like the "debt" he owes to "death" (1Henry IV 5.1.126). But Posthumus has cast himself into this prison, a "bondage" (5.3.97) he desires to escape not by evasion but by the "death" he reckons he owes as payback ("measure for measure") for Innogen's murder. Hastening into death ironically recalls the other consummations he devoutly and undevoutly wished, including the one he thinks has already been accomplished because of the "bloody cloth" (5.1.1). ${ }^{14}$ Echoes of the "debt" put off by Falstaff, while "death" (its homophone) is eagerly sought by this still impetuous young man, suggest that "redeeming the time" (Ephesians 5:16) is badly served by both extremes.

This scene "foreshadows the turn toward comedy" and the "new perspective" to come, including hints in "Posthumus's more transcendental replies" of the "play's hidden awareness of the 'fact' that Christ was born in Cymbeline's reign" (Butler 2005:222). Cymbeline's combination of commercial, martial, and societal/ personal "bonds" includes multiple (false and true) promises, appraisals of what outwardly appears promising or unpromising, and the "promissory" language of assumpsit or a promise to pay (Muldrew 1998:207). But it also foregrounds promises not kept or fulfilled, or not yet accomplished, including biblical ones. By the end of act 5 , retaliation's payback is replaced by forgiveness. But the promised biblical redemption is not yet come. Even the "tribute" to Rome, the "debt" whose "arrearages" led to war, is still not paid by play's end: Cymbeline is only "promising to pay" it (5.4.459). ${ }^{15}$

\footnotetext{
${ }^{13}$ On the "manacle" or bracelet Posthumus puts on Innogen in 1.1, see Wayne (2002:288-315). Cymbeline reworks the "bonds" of The Merchant of Venice into a "credit crisis" involving this and other objects; with bonds not just as contracts, personal pledges or tokens but as a desire to "bind" (or "manacle") inseparable from fear that binding can be "loosed."

${ }^{14}$ In 5.3.1-123, he asks the "gods" (who "coined" him) to take "all" in death's final "audit," and "cancel these cold bonds," unlike creditors who "thrive" by reprieving "broken debtors" (5.3.112-115). "Consummation" is used for death in 4.2.279 and punned on with sexual consummation in Hamlet 3.1.62.

15 See also 4.2.338; 4.3.38; 4.4.28; 5.3.200; 5.4.9; 5.4.458. Cymbeline's "promissory" language includes the debt de mariage and infidelity as contractual breach of promise
} 
The exchange between Posthumus and his Jailer raises issues that are still open-ended by the end of the play, including "transcendental" ones. But it also foregrounds (in "no true debitor and creditor but it") the issue of the truth claims of double-entry itself and the problem of "credit," belief and trust, in Cymbeline as a whole. ${ }^{16}$ The ars notaria of "pen" and "ink" arithmetic, and writing of letters with which Cymbeline is filled, included "debitor and creditor" bookkeeping as a written accounting required by the "sedentary merchant" to assure the "fidelity, honesty, and truth" of his "lieutenants" (Crosby 1997:205), "agents" or "factors." It also reflected the rise of business partnerships (like the one Iachimo pretends to be "factor" for), and the need to calculate not only the profits of the company as a whole but which partners were owed what (De Roover 1974:121-128; Robson 1992:694-704).

"Debitor and creditor" accounting, from the Florentine ledger or libro dei debitori e creditori (De Roover 1974:143), was disseminated in its Venetian facing-pages form through Luca Pacioli's Summa de arithmetica, geometria, proportioni et proportionalità (Venice 1494). In Antwerp, Jan Ympyn Christoffels's redaction was translated into French and then English, as How to Kepe a Boke of Accomptes (1547). ${ }^{17}$ In England, James Peele (father of dramatist George Peele) produced How to Keepe a Perfect Reconyng after the order of the moste worthie and notable accompte, of Debitour and Creditour (1553), expanded in The Pathe waye to Perfectnes, in th'Accomptes of Debitour, and Creditour (1569). John Mellis's Briefe Instruction and Maner how to Keepe Bookes of Accompts after the order of Debitor and Creditor (1588) revised the earliest English version of Pacioli, Hugh Oldcastle's A Profitable Treatyce... of the Kepyng of the Famouse Reconynge Called... in Englysshe, Debitor and Creditor (now lost). And other English "Debitor

(5.4.207). "Forbearance" (2.5.10), used by Posthumus for this "debt," was the term not only for patience or holding back but for a creditor's "forbearance" (going without immediate payment). See Parker (2004:26-49) on "forbearance," "promise," "credit," "debt," and the "time" of romance travail before ultimate "return" in The Winter's Tale, a nexus Cymbeline shares in multiple ways.

${ }^{16}$ On "credit" (from credere) as including "trust," see Muldrew (1998: chapter 7).

${ }^{17}$ Nicolaus Petri's Dutch Practique Om te Leeren Reekenen en cypheren (1583) combined "debitor and creditor" with arithmetic; Simon Stevin began as an Antwerp "bookkeeper," wrote a double-entry treatise, and applied arithmetic to military uses (Murray 1978:213). See Parker (2009: 228-235). 
and Creditor" treatises followed, including ones that promoted the new "arithmetic" (Sullivan 2002:13).

The impact of arithmetic's "cipher" was not only as a "numeral in the arithmetic of money" but as "the principle of zero balance in the double-entry book-keeping that controlled the expanding market of credit, debt, and commodities engendered by mercantile capitalism."18 The "central role occupied by double-entry bookkeeping" and its "zero balance" contributed to breaking down resistance to arithmetic's "infidel $\mathrm{O}^{\prime}$ in Europe (Rotman 1987:7). In England, however, Roman numerals continued to be used with "infidel symbols" in account ledgers, just as "counters" and "tally sticks" (for reckoning the "score") appear with double-entry's "books" in Shakespeare. ${ }^{19}$ Henry VI Part 2 invokes a past that "had no other books but the score and the tally" (4.7.35). But "debitor and creditor" bookkeeping and "arithmetic" were increasingly central to England's "culture of credit." The theater district was a center of reckoning schools and accountants who taught arithmetic with double-entry. Humphrey Baker, whose "arithmetic" book The Wellspring of Sciences (1574) was frequently reprinted, "plastered the district" with his promotional "bills," including a 1590 broadsheet advertising his teaching of "debitor and creditor" accounting with "Arithmetike vulgar" and "international currency exchange" (Woodbridge 2010:65-67).

In ways suggestive for Cymbeline, Baker's 1590 broadsheet also advertised surveying (or "How to measure") "Landes, Woods, and all other platformes whatsoeuer" and how to "rectifie, and make perfect any difficult or intricate account, depending in variance between two, or more partners, and thereby to shewe, which of them shall be indebted the one to the other." Its "account of foure Partners, to be rectified and made perfect by the order of Debitor and Creditor" included "Foure Merchants entred into Partnership, that is to say, A.B.C. and D. with this condition following: that all four

\footnotetext{
18 Money required "a system of writing, which included book-keeping and calculation, to enable it to function as an international medium of exchange" (Rotman 1987:78).

${ }^{19}$ There were also fears that arithmetic's "Arabic figures could more easily be forged" than Roman numerals (Thomas 1987:120), including the "O" that could fraudulently multiply by strategic insertion (Kaplan 2000:102). See Parker (2009:236-238); Aho (2005:28ff.).
} 
Should keepe account of their dooings in companie." Baker, like others in England, thus provided arithmetical "accounting" solutions to commercial problems similar to those that led to doubleentry in Italy, including how to reckon credits and debts in partnership situations.

Double-entry treatises stressed the accountant's "scrupulous fidelity to his own word" and procedures to guarantee the account's honesty and credibility or "credit" (Sullivan 2002:28, 40, 155). Pacioli's instruction to put the "name of Jesus" or "sign of the Cross" at the account's beginning - as a pledge of "trust and fidelity" as well as the "good credit" of an "unblemished reputation" (Aho 1985:29) - was repeated in Ympyn and reflected in English doubleentry treatises, including in Mellis's emphasis on "Fidelitie," "Fayth," "honesty," and "truth" (Mellis 1588:10; Poovey 1998:41). However, though it invoked the "fidelity" of the biblical "faithful steward" (Murray 1978:190, 205), double-entry's "impression of honesty" could be only a "show of religiosity" (Aho 1985:32, 29). Though its "formal precision" made it "seem accurate" (Poovey 1998:56), "double-entry bookkeeping guaranteed clarity but not honesty" (Crosby 1997:208). The "ledger was open for all to see," yielding a "fiction of total disclosure" that promised to make it possible to "see and know"; but "the inventory and the journal were secret books" and the "zero balance" was a self-enabling "fiction" (Poovey 1998:58-64). As Kaplan comments (2000:110): "the idea was simple: tote up your credits and debits on the same page of your trading account's ledger, in parallel columns. If the difference between them is zero, your books are balanced, showing your accounts were accurately kept (or skillfully cooked)."

Like the "infidel $O$," the suspect honesty of "debitor and creditor" accounting was linked to the female "count" and double entendres on "account books" (Parker 2009:231). Though doubleentry ensured that "no one else had access to the family treasure," the ledger, its "most public book," claimed to open the private to the

\footnotetext{
20 See Parker (2009:235-238). "Debitor and creditor" was thus linked to the cross complexly evoked in Pisanio's (false) "bloody sign" (3.4.124), which recalls both the bloody red cross ensign of Christ's death and resurrection and Redcrosse knight (whose erring, impulsivity, and desire for death is echoed in Posthumus's), from Book 1 of Spenser's Faerie Queene, where despair's cure includes Fidelia. See also Maley (2008:128) on the crosses of St. George and St. Andrews.
} 
eye's inspection (Poovey 1998:34-35). "PUBLIC LEDGER" was slang for "prostitute because like that paper she is open to all parties" (Williams 1994:1.131-132). Shakespeare's Sonnet 136 combined "account" with "a treasure," a "thing" of "great receipt," a "nothing," and a female "will," while "lenders' books" were juxtaposed with "brothels" and "plackets" in King Lear (3.4.95-8). In Much Ado About Nothing, "I see, lady, the gentleman is not in your books" (1.1.79) suggests "account books of a tradesman in which creditable customers were listed" (McEachern 2006:154). But its slander plot, like Cymbeline's, ultimately exposes the dishonesty of the slanderer's "accounts."

The impression of fidelity and truth created by "debitor and creditor" accounting is crucial for this play, where Iachimo's "inventory" and untrue "story" of his night in Innogen's "chamber" (2.2.27-30;2.4) provides "simular proof enough" (5.4.200) to Posthumus that Innogen is untrue. The fact that an accountant could appear honest, when an account was forged, is crucial to the wager plot. But concern that there is "no true debitor and creditor" accounting provides an important context for multiple accounts and truth claims in this play, including other slanderous accounts that affect the "good credit" of an "unblemished reputation."22 "Counterfeiting" (applied by Posthumus to the female "count," coining "counterfeit" or bastard issue with some "coiner," 2.5.5-6) characterizes Iachimo's account. But it also extends to the larger problem of "simular proof," in this play filled with false or wrongly deciphered "signs," as well as simulacra and doubles, including the commercial and biblical as potential lookalikes.

Cymbeline's central slander plot begins in the wager scene in Rome, where "country matters" sound in the praise of "our country mistresses" (1.4.45-46); and men from different countries evoke the Europe whose differences of measurement, coinage, and valuation led to the need for arithmetic as well as "debitor and creditor"

\footnotetext{
${ }^{21}$ Iachimo also slanderously reports the turned-down "leaf" of Ovid's Metamorphoses where "Philomel gave up" (2.2.45-46), recalling the "two-leaved book" as "a woman opening to receive a man" in Ovid's Amores III.xiii (Williams 1994:1.131-132).

22 This includes Belarius (3.3); and Pisanio (4.2.311-328), assumed by Innogen to be a murderer and counterfeiter of "forgèd letters." Cymbeline also foregrounds the competing truth claims of different historical accounts (Floyd-Wilson 2003:166-180; Kerrigan 2008:115ff.).
} 
accounting. The scene begins with news accounts from Britain, as the men use differing assessments to weigh up the newly-arrived Briton. Iachimo finds him wanting, invoking the inventorial language of his appraisal on an earlier occasion: "I could have looked on him without the help of admiration, though the catalogue of his endowments had been tabled by his side, and I to peruse him by items" (1.4.3-5).

The language of price, prize, praise, and appraise familiar from The Merchant of Venice pervades the fidelity-wager that ensues. Posthumus, already given to zero-sum games like dueling (in ways that make fighter-gambler Cloten his double), not only assents to the wager. He pledges Innogen's gift to him of her mother's "ring" (sign, like the bracelet, of the female "O," but also of his promise to be "true"), which Iachimo reappraises as the "trifle" she's "outprized by" (1.4.65). Sizing up Posthumus in this high-stakes gamble, Iachimo not only calculates the amount worth risking, on the odds that he will win (10,000 ducats, much more than Shylock's 3,000), but what it would take to provide "sufficient testimony" (1.4.121) to this impulsive Briton that he has "enjoyed" the "dearest bodily part" of his "mistress" (1.4.122). This may also contribute to his decision in 2.2 not to rape Innogen, but to make away quickly with what he calculates would for Posthumus be "simular proof enough" (5.4.200).

In his mercantile "voyage upon" Britain to pursue his "advantage" (1.4.104, 128), Iachimo cynically exploits the Parable of the Talents (1.6.78-82) used to justify usury, profit, or "vantage." He reports that the "gamesome" Posthumus has been using Innogen ("which I account his") as his personal cash account, "coffers" or "purse," 23 while "partnered" with "diseased ventures" (prostitutes and gambling risks). He urges her to "be revenged" by taking him as

\footnotetext{
23 The marriage chests or cassone important for Cymbeline 2.2 (Butler 2005:31) were already combined with double-entry's "cash" account (Pacioli's cassa or account of the "Chest, or purse" as "ready money," Mellis 1588:C2r,D4iiir) in the casket/chest linked to the "rich prize," "price," or treasure of Portia in The Merchant of Venice (Jaffe 1999:66-84). This "cash account" as a "secret" case or chest was associated with the female "count" or "case" (Parker 2009:230-232; OED cash n. 1; case n. 2), whose sexual sense Cloten's desire to "understand" Innogen's "case" makes explicit (2.3.70). On the case/casket/female "treasure"/trunk, see also Parker (1987:134-138); with Pichter (2005:152-154) on "trunk," "chest," and Boccaccio's cassa; Belsey (1999:55-62) on the marriage chest; Parker (2009:230-231) on John Florio's cassa, chest, casso, cashier, Cassio, and Ben Jonson's "Cash."
} 
her lover (1.6.78-139). But when she refuses to "credit" his "false report" (a term used in this scene for belief as well as fidelity and trust) and calls for help to expose this "saucy stranger" come to "mart $\mid$ As in a Romish stew" (150-152), he assures her that he "adventured" this untrue account only to test her (172-173). Shifting strategy, he poses as "factor" for a business partnership ("Myself and other noble friends | Are partners in the business," 1.6.183-184), who needs "safe stowage" (192) for its valuables: "Some dozen Romans of us and your lord $\mid[\ldots]$ have mingled sums $\mid$ To buy a present for the Emperor,|Which I, the factor for the rest, have done|In France" (185-188). His stratagem for gaining access to her "chamber" (as he will that night in the "trunk" he claims contains this "present") is thus a "business" in which Innogen has a double-meaning "interest" (1.6.195), the term used earlier for the bond with Posthumus in which she is creditor as well as debtor (1.3.30).

The scene's commercial language ("material," "tender," "promise," "short my word," "length'ning my return," "truly yielded") includes the unsuspecting Innogen's willingness to "pawn" her own "honour" (1.6.194) to protect the property of a company of which her "lord" is partner. Even before the "moveables" of her "chamber" become part of the "inventory" and "story" retailed by this dishonest "factor" (2.2.27-30), it is an "honour" in which Posthumus has a double stake (sexual and "material"), because of the contracted wager. In this play where seeming opposites become mirrors or doubles for one another, Iachimo's untrue account of a partnership simultaneously reflects a truth about Posthumus his opponent/partner. "Partners" evokes business partnerships like those bound up with arithmetic and double-entry bookkeeping in Baker and others, including the combination of competing and common interests the new arts of calculation were designed to manage. At the same time, it recalls the homosocial rivalry-emulation of the wager scene, a company of men praising/ appraising their "country mistresses," with the risk of opening private property to theft.

Cymbeline's wager plot strikingly evokes "debitor and creditor" accounting and arithmetic again in act 2. In 2.2, Iachimo substitutes his "inventory" for rape. And in 2.4, he invokes the "circumstances" central to double-entry's claim to honest accounting. "Circumstances" were the "interrogatory questions" Pacioli took 
from Roman rhetoric's technique for amplifying a discourse, which were also used in "the confessional interrogation of the penitent" (Aho 1985:26): "quis (who), quid (what), quare (where), quando (when), quantum (how many), cum quo (in whose presence), and cur (how)." Double-entry thus brought together the "business account" and "confessional account" in ways reflective of Pacioli's training in rhetoric but also in a "Franciscan monastery where weekly confession was the rule" (Aho 1985:26). English double-entry treatises likewise stressed the importance of these "circumstances" or answers to "interrogatories," crucial to judicial examination and proof (Parker 2009:234-235). ${ }^{24}$

That the "interrogatories" and "circumstances" essential to a narrative account were required in "debitor and creditor" accounting is important for Cymbeline as whole. It opens with accounts of offstage events and repeatedly foregrounds demands for detailed reports by characters not present themselves. Demands for a full and complete account (or narrative recounting) range from Innogen's questioning of Pisanio to Cymbeline's more inquisitional demands, under threat of torture if his interrogatories are not completely and honestly "answered." But this play is also filled with "counterfeit" or false accounts, as well as accounts that are deceptively partial (in both senses), including Belarius's "story" to the "sons" who think he is their father (3.3.44-78). Even Belarius's first account in the final Recognition Scene is both partial and untrue (5.4.16-19). ${ }^{25}$

Iachimo's account to Posthumus of his night in Innogen's "chamber" begins with the promise of the faithful "debitor and creditor" accountant: "my circumstances|Being so near the truth as I

\footnotetext{
${ }^{24}$ See also Parker (1996:354-355); Poovey (1998:37-58) on double-entry's "balance," designed to resemble divine order, symmetry, and rectitude as well as the scales of justice; Jaffe (1999:66) on its use of purgatio for "reconciling the books," suggestive for Cymbeline as tragicomic romance since "purgation" involved examination, trial, and contrition before "reconciliation"; and Parker (2009:235) for work on double-entry's "power-knowledge apparatus" as a "practice of inquisitio." See Cymbeline 4.3.12; 4.4.14; 5.4.133-139 for demands to render an account under threat of "torture;" or "death" (3.5.80-98); and 4.2.360-366, where the "circumstances" are evoked in Lucius's questions to Fidele. See also Meek (2009:194). On inventory and "invention," see Parker (1987:136) and Aho (2005:63ff.).

25 Even Innogen as faithful "Fidele" creates untrue stories while being "true" to Posthumus (eg. 4.2.376-378), a variation of Pisanio's "Where I am false, I am honest; not true, to be true" (4·3.42). See also Betteridge (2013:234-235).
} 
will make them,| Must first induce you to believe" (2.4.61-63). But "make" suggests something forged, even as he claims his "circumstances" need no confirming "oath" (65). The evidentiary circumstances compiled by this "factor" include what he "writes" down or "notes" in his "inventory" (2.2. 24-30). But he also stores in the accountant's Memorandum Book of his own memory some "natural notes about her body" (2.2.28), including the "mole" (38) crucial in 2.4, where the circumstances of his "story" and narrative recounting prove essential. The sight of the "manacle" or bracelet is not enough without Iachimo's false account of how Innogen took it off (2.4.95-106; Wayne 2002:288-295). And Posthumus does not finally credit Iachimo until his story refigures her innocent "mole," not as a "natural" mark or "note" but as a double-meaning "stain" (2.4.135-139). ${ }^{26}$ This then quickly becomes, in Posthumus's rapid reckoning, the assumed infidel " $\mathrm{O}$ " as a bodily stain as large as "hell can hold" (140), mistakenly deciphered sign that his private "account" has become an "open book."

The cassa, "case," or unlocked "treasure" (2.2.42) at stake for Posthumus is the female "count" that sounds not only in "Spare your arithmetic; never count the turns" (2.4.142) but in what Innogen should "from encounter guard" (2.5.19), as Posthumus visualizes Iachimo as a lusty German "boar" penetrating it with a cry of "Oh!" (2.5.16-17). ${ }^{27}$ Iachimo is already Cymbeline's Iago: but in Posthumus's jealous-voyeuristic imagining of him taking his "place" in Innogen's "bed" (5.4.185), he becomes its "lieutenant" Cassio as well. ${ }^{28}$ Posthumus's conclusion that the "woman's part" (2.5.20) is unfaithful, and he himself is a "counterfeit" coined by some "coiner" $(2.5 \cdot 5-6)$, is an ironic reminder that the currency of the wager plot itself is counterfeit coin. And the forgery depends on Posthumus's own coining of "simular proof" in the forge of his imagination, becoming Iachimo's partner in this as well.

\footnotetext{
${ }^{26}$ That seeing is impacted by Iachimo's narrative telling is clear when the same bodily "mark" or "stamp" on Guiderius is viewed through a different cultural lens in 5.4.363373. See also Lyne (2013:59).

27 See Lyne (2011:156). On "German"/"Geminus," double or twin, see Parker (1987:69-77; 1996:127-131).

${ }^{28}$ On "lieu-tenant" in the sexual sense, see Parker (1996:246).
} 
In the final Recognition Scene of Cymbeline, the "circumstances" of a complete accounting are invoked yet again. Cymbeline's "When shall I hear all through? This fierce abridgement|Hath to it circumstantial branches" (5.4.388-389), combines the detailed narrative ramifications of too short an account with the "branches" of his own genealogical tree. His "Where, how [...] when [...] how [...] whither" and other questions to be "demanded," once again invoke the "interrogatories" of "debitor and creditor," something that in the "abridgement" of dramatic "show" there is not time to "tell": "But nor the time nor place|Will serve our long inter'gatories" (5.4.392-393).

Before this, Iachimo's amplified narrative "circumstances" produce the longest account in the entire play. Under Cymbeline's threat of "torture" if he does not tell the truth (5.4.133), Iachimo tortures the King himself by repeatedly breaking off, while claiming his reluctance to get to the point because his revelations would "torture" his hearer (140). His account is staged as if it were a "confession." But it is risky to take Iachimo's consummate performance at face value, as reliable coin. Once again, he manipulates the power of circumstantial evidentia or enargeia (Parker 1987:138-140; 1996:242-245), voyeuristically picturing events for those who were not there. His "confessional" account simultaneously exploits rhetoric's potential for the counterfeit or "simular," through ambiguous inferences about what cannot be seen (or known) about the details his account includes, or about the accountant himself beyond his own controlled "show." Paradoxically, what appears to be the fullest account in the play, in response to the demand for a complete and honest accounting, is deceptively partial, putting on display his continuing ability to appraise or calculate what to picture to (and withhold from) a particular audience.

Cymbeline's biblical echoes provide reminders that the ultimate Recognition Scene of Revelation or Apocalypse is only "foreshadowed," a "promise" not yet accomplished and "redemption" still to come. The foregrounding within it of the difficulty of "distinction" or "partition" (1.6.37), amidst proliferating simulacra and doubles, underscores that the definitive separation of "counterfeit" from "true" awaits that ultimate Revelation or unmasking, where the Luciferic lookalike (and dissimulating 
accountant) will be replaced by the Redeemer called "Faithful and True" (Revelation 19:11). ${ }^{29}$ By Cymbeline's end, however, even the New Testament Epiphany is still in the future, awaiting a Nativity that has not yet occurred. In the play itself, there is no final (or "true") "debitor and creditor," Audit, or Reckoning, and no perfect "Faithful and True." 30 Even "Fidele" is revealed as Innogen, at the same time as "play" and "part" (5.4.228-229) call attention to the playing of her "woman's part" by a boy actor, in a transvestite English theater that itself dissimulates and simulates, requiring the audience to see double, boy player and female character restored.

Cymbeline foregrounds the problem of uncertain "knowledge" (1.1.6o) and cognitive impenetrability (Spolsky 2004:72-79), but also the perils of interpretive certainty. Its echoes of 1 Corinthians 13 (where knowing is only "in part" and seeing is per speculum in aenigmate, through an enigmatic mirror or "glass darkly") provide a wrying perspective on the play's own enigmas and decipherings. The Roman "Soothsayer" Philharmonus, official decipherer of enigmatic signs, may be a reliable "sooth" (or truth)-sayer; or, from another perspective, an imperial spin-meister, able to adapt his answers to the new prospects and "circumstances" of changing times.

In the more contemporary context of "sooth"-saying evoked by the Jailer's "no true debitor and creditor but it," double-entry accounting was a "vehicle for producing public knowledge - that is, knowledge that was designed to function in public as a sign of something more than the information included in the books" (Poovey 1998:37). Its own claims to certain knowledge, as well as truth-telling, depended in its final ledger or "book" on numbers that

\footnotetext{
${ }^{29}$ See Parker $(1996: 56-82,367)$ on biblical lookalikes, counterfeits, and simulacra in The Comedy of Errors, including the "devil" disguised as "angel of light" (2 Corinthians 11:14) also exploited in Othello (2.3.351-352; 1.3.16-19); Parker (2009:238).

${ }^{30}$ In Book I of Spenser's Faerie Queene, the period of romance "error" is the time before this final Revelation and knight "Faithful and True." Cymbeline's setting "pre" the birth of Christ is also relevant to a critique of empire, since the imperial Rome and Augustan pax emulated by James were surpassed by the Rome that could not be seen. Reminders in Jupiter's descending eagle of the rape of Trojan Ganymede (cause of Juno's revenge on Troy's descendants) also complicate more straightforward praise of James; and need to be added to the other ways this play ironizes Jupiter as well as James, cited, inter alia in Palfrey (1997:243-250); Maley (2003:31-44; 2008:119-137); King (2007:92-95). On the Soothsayer, see Throne (1999:189); Betteridge 2013:236).
} 
purported to provide evidence of things in themselves (Poovey 1998:64). Its borrowings from an older religious language confessional "interrogatories" and purgatio for the reconciling of its "books" - may have given this system of knowledge production the "credit" to which it aspired. But even in the commercial "culture of credit" that was Shakespeare's contemporary context, there were skeptical voices and fears that its claims to honesty and certain knowledge were susceptible to simulation and fraud. Cymbeline provides crucial reminders that "evidence" is inseparable from evidentia, the rhetorically counterfeited illusion of definitive proof, just as double-entry itself as warrant of truth was based on its own fictions, forging the appearance of accounts that could be trusted.

The importance of "arithmetic" and "debitor and creditor" accounting is thus not restricted to the scenes in Cymbeline in which they are invoked by name. Rather, both are central to the language and preoccupations of this combination of "Roman," romance, and "bourgeois" plot.

\section{References}

Aho, James 1985. "Rhetoric and the Invention of Double-Entry Bookkeeping." Rhetorica 3/1:21-43.

2005. Confession and Bookkeeping. Albany: State University of New York Press.

Bady, David 1985. "The Sum of Something: Arithmetic in The Merchant of Venice." Shakespeare Quarterly 36/1:10-30.

Baker, Humphrey 1574. The Wellspring of Sciences. London.

ca. 1590. "Such as are desirous, either themselves to learn, or to have their children or servants instructed in any of these arts and faculties here under named, it may please them to repair unto the house of Humphry Baker." London: Thomas Purfoot [?]. STC 1209.3. Broadsheet.

Belsey, Catherine 1999. Shakespeare and the Loss of Eden. New Brunswick: Rutgers University Press.

Bernstein, Peter L. 1996. Against the Gods: The Remarkable Story of Risk. New York: John Wiley \& Sons.

Betteridge, Thomas 2013. "Writing faithfully in a post-confessional world." Eds. Andrew J. Power and Rory Loughnane. Late Shakespeare, 1608-1613. Cambridge: Cambridge University Press: 225-242. 
Blank, Paula 2006. Shakespeare and the Mismeasure of Renaissance Man. Ithaca: Cornell University Press.

Boyer, Carl B. 1968. A History of Mathematics, second ed. rev. Uta C. Merzback. New York: John Wiley \& Sons.

Butler, Martin 2005. Ed. Cymbeline. Cambridge: Cambridge University Press.

Crosby, Alfred W. 1997. The Measure of Reality: Quantification and Western Society, 1250-1600. Cambridge: Cambridge University Press.

Digges, Leonard and Thomas 1579. An Arithmeticall Militarie Treatise, Named Stratioticos. London.

Digges, Thomas 1590. An Arithmetical Warlike Treatise Named Stratioticos. London.

De Roover, Raymond 1974. Business, Banking, and Economic Thought in Late Medieval and Early Modern Europe. Ed. Julius Kirshner. Chicago: University of Chicago Press.

Edelman, Charles. 2000. Shakespeare's Military Language: a dictionary. The Athlone Press.

Evans, G. Blakemore and J.J.M. Tobin. eds. 1997. The Riverside Shakespeare. Second Edition. Boston: Houghton Mifflin.

Fischer, Sandra K. 1985. Econolingua: A Glossary of Coins and Economic Language in Renaissance Drama. London: Associated University Presses.

Floyd-Wilson, Mary 2003. English Ethnicity and Race in Early Modern Drama. Cambridge: Cambridge University Press.

Gillen, Katherine 2011. "Chaste Treasure: Protestant Chastity and the Creation of a National Economic Sphere in The Rape of Lucrece and Cymbeline." Early English Studies 4: 1-38.

Glimp, David, and Michelle Warren, eds. 2004. Arts of Calculation: Numerical Thought in Early Modern Europe. New York: Palgrave Macmillan.

Hadden, Richard W. 1994. On the Shoulders of Merchants: Exchange and the Mathematical Conception of Nature in Early Modern England. Albany: State University of New York Press.

Hawkes, David 2010. The Culture of Usury in Renaissance England. New York: Palgrave Macmillan.

Jaffe, Michele Sharon 1999. The Story of O: Prostitutes and Other Good-for Nothings in the Renaissance. Cambridge: Harvard University Press.

Kaplan, Robert 2000. The Nothing that Is: A Natural History of Zero. Oxford: Oxford University Press.

Kerrigan, John 2008. Archipelagic English. Oxford: Oxford University Press. 
King, Ros 2007. "In Lieu of Democracy, or How Not to Lose Your Head: Theatre and Authority in Renaissance England." Eds. Subha Mukerji and Raphael Lyne. Early Modern Tragicomedy. Cambridge: D. S. Brewer: 84-100.

Korda, Natasha 2009. "Dame Usury: Gender, Credit and (Ac)counting in the Sonnets and The Merchant of Venice." Shakespeare Quarterly 60/2: 129-153.

Lyne, Raphael 2011. Shakespeare, Rhetoric, and Cognition. Cambridge: Cambridge University Press.

2013. "Cymbeline: Recognition in Cymbeline." Eds. Andrew J. Power and Rory Loughnane. Late Shakespeare, 1608-1613. Cambridge: Cambridge University Press: 56-70.

Maley, Willy 2003. Nation, State, and Empire in English Renaissance Literature. New York: Palgrave Macmillan.

2008. "Cymbeline, the Font of History, and the Matter of Britain: From Times New Roman to Italic Type." Ed. Diana E. Henderson. Alternative Shakespeares 3. New York: Routledge: 119-137.

McEachern, Claire 2006. Ed. Much Ado About Nothing. London: Thomson Learning.

Meek, Richard 2009. Narrating the Visual in Shakespeare. Farnham: Ashgate.

Mellis, John 1588. A Briefe Instruction and maner how to keepe bookes of Accompts after the order of Debitor and Creditor. London.

Menninger, Karl 1969. Number Words and Number Symbols. Cambridge, Mass.: The M.I.T. Press.

Muldrew, Craig 1998. The Economy of Obligation: The Culture of Credit and Social Relations in Early Modern England. London: Macmillan.

Murray, David 1978. Chapters in the History of Bookkeeping, Accountancy, $\mathcal{E}$ Commercial Arithmetic. New York: Narno Press.

Nosworthy, J. M. 1955. Ed. Cymbeline. London: Methuen.

Pacioli, Luca 1494. Summa de arithmetica, geometria, proportioni et proportionalità. Venice.

Palfrey, Simon 1997. Late Shakespeare: A New World of Words. Oxford: Oxford University Press.

Parker, Patricia 1987. Literary Fat Ladies: Rhetoric, Gender, Property. London: Methuen.

1989. "Romance and Empire: Anachronistic Cymbeline." Eds. George M. Logan and Gordon Teskey. Unfolded Tales. Ithaca, Cornell University Press: $189-207$. Press. 
2004. "Temporal Gestation, Legal Contracts, and the Promissory Economies of The Winter's Tale." Eds. Margaret W. Ferguson and Nancy E. Wright. Women, Property, and the Letters of the Law. Toronto: University of Toronto Press: 25-49.

2009. "Cassio, Cash, and the 'Infidel o': Arithmetic, Double-entry Bookkeeping, and Othello's Unfaithful Accounts." Ed. Jyotsna G. Singh. A Companion to the Global Renaissance. Oxford: Wiley-Blackwell: 223-241.

Parolin, Peter A. 2002. "Anachronistic Italy: cultural alliances and national identity in Cymbeline." Shakespeare Studies 30: 188-215.

Peele, James 1553. The maner and fourme how to kepe a perfecte reconyng, after the order of the moste worthie and notable accompte, of Debitour and Creditour. London.

1569. The Pathe waye to Perfectnes, in th'Accomptes of Debitour, and Creditour. London.

Pitcher, John 2005. Ed. Cymbeline. London: Penguin Books Ltd.

Poovey, Mary 1998. A History of the Modern Fact: Problems of Knowledge in the Sciences of Wealth and Society. Chicago: The University of Chicago Press.

Raman, Shankar 2008. "Death by Numbers: Counting and Accounting in The Winter's Tale." Ed. Diana E. Henderson. Alternative Shakespeares 3. New York: Routledge: 158-180.

- 2010. "Specifying Unknown Things: The Algebra of The Merchant of Venice." New York: Routledge: 212-231.

Recorde, Robert 1543. The Ground of Artes. Teachyng the worke and practise of Arithmetike. London.

Robson, Keith 1992. "Accounting Numbers as 'Inscription': Action at a Distance and the Development of Accounting." Accounting, Organizations and Society 17/7: 685-708.

Rotman, Brian 1987. Signifying Nothing: The Semiotics of Zero. New York: St. Martin's Press.

Ryner, Bradley D. 2008. "The Panoramic View in Mercantile Thought: Or, A Merchant's Map of Cymbeline." Eds. Barbara Sebek and Stephen Deng. Global Traffic: Discourses and Practices of Trade in English Literature and Culture from 1550 to 1700 . New York: Palgrave Macmillan: 77-94.

Seife, Charles 200o. Zero: The Biography of a Dangerous Idea. New York: Penguin.

Siemon, James R. 1994. "Perplexed beyond self-explication': Cymbeline and early modern/postmodern Europe." Eds. Michael Hattaway, Boika Sokolova and Derek Roper. Shakespeare and the New Europe. London: T\&T Clark: 294-309. 
(c) ederi 23 (2013)

Spolsky, Ellen 2004. "Women's Work is Chastity: Lucretia, Cymbeline, and Cognitive Impenetrability. Eds. Alan Richardson and Ellen Spolsky. The Work of Fiction: Cognition, Culture, and Complexity. Aldershot: Ashgate: 5184 .

Spurgeon, Caroline F. E. 1935. Shakespeare's Imagery and What It Tells Us. Cambridge: Cambridge University Press.

Stanivukovic, Goran V. 1998. "The city's usuries': Commerce and Cymbeline." Quidditas 19: 229-243.

Sullivan, Ceri 2002. The Rhetoric of Credit: Merchants in Early Modern Writing. London: Associated University Presses.

Swetz, Frank J. 1987. Capitalism and Arithmetic. La Salle, Illinois; Open Court Publishing Co.

Thomas, Keith 1987. "Numeracy in Early Modern England." Transactions of the Royal Historical Society, Fifth Series, 37: 103-132.

Thorne, Alison. "To write and read / Be henceforth treacherous': Cymbeline and the Problem of Interpretation." Eds. Jennifer Richards and James Knolles. Shakespeare's Late Plays: New Readings. Edinburgh: Edinburgh University Press: 176-190.

Turner, Henry S. 2006. The English Renaissance Stage: Geometry, Poetics, and the Practical Spatial Arts. Oxford: Oxford University Press.

Wayne, Valerie 2002. "The woman's parts of Cymbeline." Ed. Jonathan Gil Harris and Natasha Korda. Staged Properties in Early Modern English Drama. Cambridge: Cambridge University Press: 288-315.

- 2008. "Romancing the Wager: Cymbeline's Intertexts." Ed. Mary Ellen Lamb and Valerie Wayne. Staging Early Modern Romance. London: Routledge: $163-87$.

Williams, Gordon 1994. A Dictionary of Sexual Language and Imagery in Shakespearean and Stuart Literature. 3 vols. London: Athlone Press.

Woodbridge, Linda 2003. Ed. Money and the Age of Shakespeare: Essays in New Economic Criticism. New York: Palgrave/St. Martin's.

2010. English Revenge Drama: Money, Resistance, Equality. Cambridge: Cambridge University Press.

How to cite this article:

Parker, Patricia. "Cymbeline: Arithmetic, Double-Entry Bookkeeping, Counts, and Accounts." SEDERI 23 (2013): 95-119.

Submission: 12/07/2013-Acceptance: 5/09/2013 